\title{
Performance of Agricultural Regulated Markets in Tripura-A Quest for Rapid Development
}

\author{
Rajib Mallik
}

\begin{abstract}
Regulated market occupies a place of foremost importance in the contemporary agricultural marketing scenario of Tripura. It is very much helpful for economic growth of a state and as well as for a country. At present, there are 21 regulated markets in the state of Tripura. In this state, the first regulated market was establislled in the year 1964 at Bishalgarh, west Tripura. Afterward, 3 markets were regulated in 1981 and 17 markets were regulated in 1986. Since 1986, no market of Tripura has been regulated. The Government of Tripura has taken several steps to streamline the regulated market system. But, the improper functioning of most of the regulated markets and other handicaps has not changed the conditions noticeably. Still a major part of rural markets are working outside the frame of regulated market. As a matter of fact, in Tripura the structure and system of marketing and consumer distribution is mostly dominated by private traders causing a hassle in the overall development of the regulated markets. To improve the prevailing conditions of these markets, at that instant, market regulation becomes further essential. The paper overviewed the regulated markets of Tripura focusing on its present status, market practices, problems and performances. In this regard, the study basically has analyzed the physical and financial performance of regulated markets in Tripura. It provides few guidelines for the primary producers to get the best possible returns from the agricultural regulated markets. At last, some valuable suggestions have also been offered for rapid development of regulated markets in the state.
\end{abstract}

Index terms: Consumer Distribution, Contemporary, Dominated, Prevailing Conditions, Primary Producers.

\section{INTRODUCTION}

In India, agriculture is the largest sector of economic activity. It is aptly remarked for India that "increasing agricultural productivity makes important contributions to economic development and that, with him considerable limits at least, it is one of the precondition which must be established before, a take-off into self-sustained economic growth becomes possible" (Nicholls,1985). But, an important problem of Indian agriculture concerns the marketing of its produces (Agarwal, 1988). Various studies stand to confirm that, in India, instead of the producer getting the benefits, the middlemen are enjoying the cream at the cost and disability of Indian farmers. The system of marketing is sufficiently inefficient, inelastic to the hard luck of farmers and consumers who are crushed. That's why the proper functioning of regulated markets is quite important for the different states of the country (Agarwal, 2005).

The system of regulated markets has been found to be very useful in removing fraudulent practices followed by brokers and commissions agents and in standardizing market practices. Moreover, regulated markets provide for settlement of disputes, if any, amongst the sellers and buyers (Datt and Sundharam, 2004). It helps the farmers to secure fair prices for their produces. Regulated markets are greatly successful in some particular states like Punjab; Haryana etc. (Prasad, 1985). In this perspective, the Government went for comprehensive and rapid expansion of regulated markets in different states of India.

The Government of Tripura has enacted the Agricultural Market Produce Act(AMPC) with an aim to provide better regulations of buying and selling of agricultural produces and for establishment of regulated markets in the state (Report of Director of Marketing, 2007-08). The Government has taken numerous steps for development of regulated market in Tripura. In spite of these initiatives, there are no such noticeable changes in the scenario of regulated markets of Tripura. This is basically for improper regulation and functioning of regulated markets in Tripura (from, quite a few researches and market survey result).

\section{REVIEW OF LITERATURE}

The literature on regulated markets of Tripura is not numerous and it is scattered. No such book is available on the regulated market of Tripura. Even, only a few numbers of books are available on the regulated market of India, but numerous numbers of books are available on agricultural marketing along with a few discussions on regulated markets. It is noteworthy that many researchers have studied regulated markets from different views and in different contexts. That's why, a larger number of studies have been carried out on all rural situations and agricultural marketing to procure knowledge on regulated markets.

Prasad, A Sivarama (1985), in his book of Agricultural Marketing in India, discussed the market regulation, administration, market amenities and facilities, market practices and financial performance of regulated markets in India. He has also been discussed the administration, market amenities and facilities, market practices and financial performance for selected agricultural regulated marketing of Andrapradesh. He identified major problems and few strategies for developments of agricultural marketing of Andrapradesh.

Agarwal, A.K, (1988), in his study, "North Eastern Economy: Problems \& Prospect" discussed about the North-Eastern economy, problems and prospects, including 
the agricultural regulated markets problems in North-East India. He has been analyzed the agricultural marketing system in Northeastern States, rural marketing system in Assam, perceptions of farmers on rural marketing, problems in agricultural marketing.

Chakraborty and Halder (1995), in his book of Rural Market and Marketing in Tripura, discussed about rural market and marketing in Tripura with special reference to agricultural marketing, He established that developments of regulated markets are one of the prime factors to provide economic steadiness to the farmers and this can be possible when there is prefect integration on different possessions like the production costs, the market price of the produce, standardization of quality etc. $\mathrm{He}$ concluded that simultaneous developments of all these components are awfully important for the development of the regulated markets.

Bankar, Basavaraja and shankaramurthy, H.G. (2000), in their paper, "Impact of investment of performance of regulated markets n Karnataka", analyses the comparative performance of regulated markets during pre and post -investment periods (physical and financial indicators combined). They stated that there is a need to provide adequate funds for development of less developed markets. They also suggested on more market regulation, higher price for better quality of service and prominent publicity for regulated markets of Karnataka.

Ghosh, M.M. (2000), in his paper "Growth and Development of Regulated Markets in India", , analyzed the growth and development of regulated markets in India into two distinct periods-i) Pre-independence period and ii) Post independence period. He found that during pre-independence period the first act passed in 1897 in the name of Berar Cotton and Grain Markets Law. Then after, many acts passed in India such as the India Cotton Committee Act, 1927, the Royal Commission Act, 1926 etc. In the post - independence period, the five year plans visualized the importance of regulation of new markets throughout the country.

Prasad, Arbind (2000), in his paper, "Regulated Agricultural Markets in Bihar: Policy and Performance", explain about progress of regulation in Bihar. He also discussed the Government intervention in agricultural marketing in Bihar. He conducted research on market development and performance, market structure, marketing pattern, marketing channel and market access for regulated markets of Bihar. He recommended some policy measures for improving the functioning of the agricultural marketing system.

Prasad, Jadish (2000), in his book of Encyclopedia of Agricultural Marketing (Volume-1), has been analyzed the concepts, issues, development, performance of regulated markets of India. He has discussed about agricultural scenario, need for growth of marketing infrastructure and present status of regulated markets in different states of India. He stated that marketing infrastructure is most imperative not only for the performance of various marketing functions and for expansion of the size of market, but also important for transfer of appropriate price signals leading to improved marketing efficiency.
Prasad, Suresh (2000), in his paper, "Agricultural Regulated Market: A Micro Study", showed that the immense growth and development programmes have been witnessed in many states of the country during the last two decades only. In this context, he establishes that regulation of marketing becomes an important part of the state policy for improving the agricultural regulated marketing system. In this study, he had also discussed about market infrastructure, trade practices, marketing charges and cost, market amenities and facilities of regulated markets of India.

Raju, V.T. and Rao, D.V.S. (2000), in their study "Role of Regulated markets in the marketing of cultivators' produce in Andhra Pradesh", discussed about regulated markets of Andhra Pradesh. He identified the various facilities such as correct measurement by using electronic weigh bridges and weighing balances, godown facilities, bank facility, immediate payment, daily price information, rest sheds, drinking water facility, cattle sheds, free medical aid to farmers, input shops, phone and fax facilities etc. for regulated of Andhra Pradesh.

Singh, L.P. (2000), in his paper "Regulated Markets: Its Shortcoming and Measures", revealed that regulated markets are yet to bring about any substantial change in our traditional system of agricultural marketing and workings of regulated markets are allied with some limitations. He determines the major shortcoming for regulated markets of India. Some important steps for corrective measures of regulated markets of India have been discussed in his study. Beside this, some suggestions for rapid development of the markets are also specified here.

Prasad, Jagdish (2004), in his paper "Agricultural Marketing and Market Development: An Impact Evaluation Study of Regulated Market in Bihar", discussed about the role of an efficient agricultural marketing system in accelerating agricultural production. He conducted research on market functionaries, market charges, market intelligence, income of market committee, transport use pattern: arrivals and despatches and price behaviour for regulated market in Bihar.

Prasad, Raj Kumar (2005), "Agricultural Marketing Efficiency -A study of impact of market regulation in Bihar", discussed about market regulation and development in the regulated markets of Bihar. They determine the impact of market regulation on price behaviour, market arrivals, trade margin, storage, transportation and grading. They point out that for improving the functioning of agricultural regulated markets, the regulatory measures need to be strictly enforced to benefit the farmers.

Chakraborty, K.S. (2009), in his book of Rural Market and Marketing in Tripura, discussed about the marketing of agricultural produces in Tripura $\mathrm{He}$ also discussed about administration, market amenities and facilities etc. of regulated markets in Tripura. In 2000, he has narrated about rural market and marketing of agricultural produces in tribal areas.

Jairath, M.S., (2010), in his study “Agricultural Marketing Infrastructural Facilities in India - State Wise Analysis"

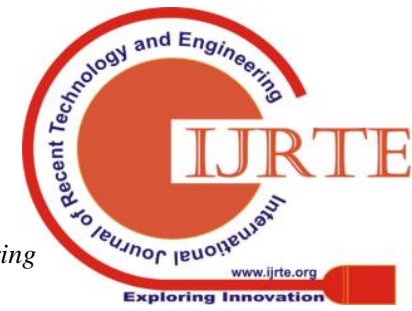


showed that there is a strong need for - (i) creation of necessary infrastructural facilities in all the regulated markets of the country, (ii) regulation of all primary and secondary wholesale markets to minimize the variation in their spread, (iii) develop the periodic/rural markets with minimum necessary infrastructural facilities as these are the main contact points for sale of agricultural produce by the small size farm operators. He also mentioned that infrastructural facilities are crucial and requires large investment, hence it is suggested that offering incentives and creating enabling conditions would increase private sector participation and enhance the availability of agricultural marketing infrastructure in the country.

Kerur, N. M. (2010), in his research paper, "Policy framework for the Agribusiness Sector-A case of performance of regulated markets in Karnataka" , enlighten about regulated markets of Karnataka, pertaining to both physical and financial indicators such as market functionaries, income and expenditure, market arrivals and commodities turnover over a period of time and operation of different promotional schemes introduced by Karnataka State Agricultural and Marketing Board and Government of Karnataka. Actually, he conducted research on growth performance, Market functionaries, Growth of market arrivals and prices of selected commodities, average income and expenditure in selected markets during 1990-91 to 2004-05.

Mallik, Rajib (2012), in his paper "Policy Reforms, Performance and Requirements of Regulated Markets in Tripura", overviewed the regulated markets of Tripura, discussing on need of market regulations, progress, requirement of regulated markets and market regulation and reforms. Beside these, amendments in the Market regulation and reforms have also been analyzed for the rapid developments of the regulated markets of Tripura.

Mallik, Rajib (2013), in his paper, "Volume of Transaction in Regulated Markets of Tripura", delineated the volume of transaction in regulated markets of Tripura. Moreover, volume of transaction in regulated markets of India and North East India has also been discussed. In this paper, volume of transaction discussed in terms of market arrival and market dispatches for all different regulated markets of Tripura. Actually, volume of transaction has been discussed for eight selected regulated markets of Tripura. Again, market wise projected arrival in regulated markets of Tripura has been discussed in this paper.

Mallik, Rajib (2013), in his paper "Market Amenities and Facilities in Regulated Markets of Tripura", overviewed the availability of market amenities and facilities in regulated markets of Tripura. Market facilities and infrastructure in selected regulated markets of Tripura have been analyzed in this study. Furthermore, market amenities and facilities in regulated of India \& North Eastern region have also been discussed.

Mallik, Rajib (2013), in his study "Market Practices in Regulated Markets of Tripura", overviewed the different types of market practices in regulated markets of India. Beside this, market practices in regulated markets of North Eastern region have also been discussed in his paper. Actually, in this study, market practices in regulated markets of Tripura have been analyzed with eight selected regulated markets. Finally, some suggestions offered for providing better market practices in regulated markets of Tripura.

Sakthivel, G. and Sangeetha, T. (2014), in their study paper, "A Study on Performance of Regulated Agricultural Market in Coimbatore District-Tamilnadu-An Overview", discussed the impact of farmers' references of regulated markets, the awareness of the respondents about the regulated markets and problems faced by the farmers by regulated markets in Coimbatore district. He stated that agricultural marketing continued to be hectic by many market imperfections such as inadequate infrastructure, lack of scientific grading system, defective weightiest and so on. He also analyzed several steps for improving the conditions of regulated markets of Tamilnadu.

There is a considerable gap in the research area associated with performance measurement, problems in functioning of regulated markets, facilities \& amenities required for development of regulated market in Tripura. On the other hand, no hypothesis was developed between the regulated market systems and specified factors like market intelligence, price, promotion, amenities \&facilities, market practice, and location of the market.

Hence, a comprehensive study incorporating the above issues is felt necessary. Against this background, it is proposed to examine present status, facilities and infrastructure, problems and financial performance of regulated markets of Tripura. Beside this, three important hypotheses developed between the regulated market systems and three specified factors, which include price, market intelligence and market practice. Moreover, some suggestions offered for innovative strategies and to construct an integrated approach for rapid development of regulated markets in Tripura.

\section{METHODOLOGY \& RESULTS}

The study is an attempt to focus into performance, problems and development of regulated markets in Tripura. It is based upon both primary and secondary data. The primary data for the study have been collected by personal canvassing of questionnaires among growers, commission agents, traders and committee officials selected in the concerned village and markets. The secondary data collected from the secondary sources like various books and reports. In the course of analyzing the issues, a number of text and references books, State Government Publications including the Publications of Agriculture Department, Economics \& Statistics Department, Govt. of Tripura, and other published and unpublished documents relating to the study have also been considered.

The number of regulated markets is not being very large in Tripura. It has, therefore, been proposed to follow the stratified sampling method to study on regulated markets of Tripura. For this study, the data have been collected from four different region of Tripura. In this regard, the eight selected regulated markets are shown in table-1: 
Table -1: Surveyed area of regulated markets in Tripura

\begin{tabular}{|l|l|}
\hline Region & \multicolumn{1}{|c|}{ Regulated markets } \\
\hline West & $\begin{array}{l}\text { (a) Regulated Market, Bishalgarh, } \\
\text { (b) Regulated Market, Champaknagar, } \\
\text { (c) Regulated Market, Teliamura, } \\
\text { (d) Regulated Market, Jumpuijala. }\end{array}$ \\
\hline South & $\begin{array}{l}\text { (a) Regulated Market, Santir Bazar } \\
\text { (b) Regulated Market, Kalashi. }\end{array}$ \\
\hline Dhalai & (a) Regulated Market Chawmanu. \\
\hline North & (a) Regulated Market, Panisagar. \\
\hline
\end{tabular}

Source: Author estimation.

According to National commission on agriculture, on an average, there will be one regulated market in every $5 \mathrm{Kms}$ radius of a circle. Then, the area of the circle $=\pi \mathrm{R}^{2}=3.14 \mathrm{x}$ $(5)^{2}=78.5 \mathrm{Sq} . \mathrm{Km}$. Thus, there is the requirement of one regulated market in every 78.5 square kms. To find out the requirement of regulated markets in Tripura, the following formula is used:

Total area (square kms)

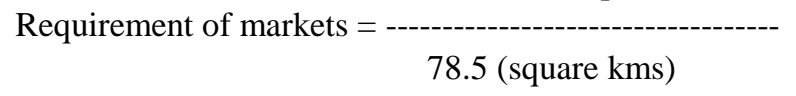

\section{Hypothesis:}

The following three important hypotheses established on the basis of the three important factors of regulated markets, which include price, market intelligence and market practice.

\section{Hypothesis -1}

$\mathrm{H}_{0}$ : The regulated market system does not affect the prices of agricultural produces in Tripura

$\mathrm{H}_{1}$ : The regulated market system affects the prices of agricultural produces in Tripura.

\section{Hypothesis- 2}

$\mathrm{H}_{0}$ : The market intelligence does not affect the marketing of agricultural produces in regulated markets of Tripura.

$\mathrm{H}_{1}$ : The market intelligence affects the marketing of agricultural produces in regulated markets of Tripura

\section{Hypothesis- 3}

$\mathrm{H}_{0}$ : The market practice does not affect by regulated market system of Tripura.

$\mathrm{H}_{1}$ : The market practice affects by regulated market system of Tripura.

One-proportion z-test has been conducted to test the selected hypothesis. The formula of the Z-test is as follows:

$$
Z=\frac{p-p_{H O}}{\sqrt{\frac{p_{H O} q_{H O}}{n}}}
$$

Here, $\mathrm{p}=\frac{X}{n}$, $\mathrm{x}$ - no of sample that given positive response \& $\mathrm{n}$ is the total number of sample.
To test the hypothesis, one structured questionnaire has been prepared for three mentioned factors- market intelligence, price, and market practice. For this purpose, 120 sample questionnaires (sample size) filled up from farmers (15 from each selected regulated market).

\section{Regulated Markets in Tripura-Progress of Regulation}

In India, market regulation has been enacted under the Agriculture Produce Markets Act, with the object to regulate sale and purchase of the agricultural products and create conditions for a fair competition. The Directorate of Marketing and Inspection, renders the necessary guidance and assistance to the states in forming legislation and its enforcement (Dhingra, 2005). In India, almost all the states including Tripura have passed legislation for market regulation. The State Government in connection with establishment of regulated markets enacts the following acts and rules in Tripura (Chakraborty , 2009). The acts and rules for regulated markets of Tripura are as follows:

1) The Tripura Agriculture produces Markets Act, 1980

2) The Tripura Agricultural Produce markets (Amendment) Act, 1983

3) The Tripura Agriculture Produce Markets (Administration) Rules, 1985

4) The Tripura Agricultural Produce markets (Second Amendment) Act, 2007

In Tripura, Agriculture Produce Markets Act, 1980 contains provisions for establishment of regulated markets and constitution of Market Committee for better regulation of products, sale, storage, etc. of specified agricultural produces. Afterward, the Tripura Agriculture Produce Markets (Administration) Rules 1985 have been established for better regulations and development of the markets. In the state, the first amendment of The Tripura Agriculture Produce Markets Act was made in 1983. The amendment was made with the specific objective of establishing a Market Board at the state level for the purpose of coordinating and supervising the functions of the market committee. In the state, the second amendment of the Tripura Agriculture Produce Markets Act was made in 2007. Through the second amendment, i.e. The Tripura Agricultural Produce markets (Second Amendment) Act, 2007, suitable provisions was made in connection with special market and special commodity market, contract farming, establishment of consumer /farmer markets, etc., but since from 2007, no amendment has made for regulated markets of Tripura.

The agriculture is one of the most important components of economy of Tripura. But, still the benefits are not percolating down to the farming community and an important problem of agriculture concerns the marketing of its produces (Agarwal, 2009). That's why; regulation of marketing becomes an essential part of the state policy for improving the agricultural marketing system. But, progress of regulation of markets in the state of Tripura is exceptionally slow (Report of Director of Marketing, 2007-08), which has exposed in table-2: 
Table -2: Progress of Regulation of Markets in Tripura

\begin{tabular}{|c|c|c|c|}
\hline $\begin{array}{l}\text { Sl. } \\
\text { No. }\end{array}$ & $\begin{array}{l}\text { Year of } \\
\text { regulations }\end{array}$ & $\begin{array}{l}\text { Name of the } \\
\text { markets. }\end{array}$ & $\begin{array}{c}\text { No of } \\
\text { markets }\end{array}$ \\
\hline 1 & 1964 & Bishalgarh & 1 \\
\hline 2 & \multirow{3}{*}{1981} & Teliamura & \multirow{3}{*}{3} \\
\hline 3 & & Santirbazar & \\
\hline 4 & & Melaghar & \\
\hline 5 & \multirow{17}{*}{1986} & Sonamura & \multirow{17}{*}{17} \\
\hline 6 & & Jampuijala & \\
\hline 7 & & Mohanpur & \\
\hline 8 & & Champaknagar & \\
\hline 9 & & Kalyanpur & \\
\hline 10 & & Bachaibari & \\
\hline 11 & & Panisagar & \\
\hline 12 & & Dasda & \\
\hline 13 & & Pabiachara & \\
\hline 14 & & Chawmanu & \\
\hline 15 & & Kulai & \\
\hline 16 & & Gandacherra & \\
\hline 17 & & Kalashi & \\
\hline 18 & & Nutan bazar & \\
\hline 19 & & Garjee & \\
\hline 20 & & Barapathari & \\
\hline 21 & & Silachari & \\
\hline
\end{tabular}

Source: Author Calculation, from Report of Director of Marketing (2007-08): Deptt. of Agriculture, Govt. of Tripura.

From the above table, it is found that the first regulated market was established in Bishalgarh (1964). Afterwards, 3 markets were regulated in 1981 and 17 markets were regulated in 1986. Since, 1986 no market of Tripura has been regulated. Due to lack of sufficient support by Central and State Government, the regulated markets have not been made significant development and still a major part of agricultural markets are working outside the frame of regulated market. Beside this, in different five-year plan -wise accreditation of regulated markets in Tripura are also quite different. As per different five- year plan, the progresses of market regulation are shown in table- 3 :

Table 3: Five year plan- wise progress of market regulation in Tripura

\begin{tabular}{|l|l|l|l|}
\hline Sl. No. & Plan & Period & $\begin{array}{l}\text { No of } \\
\text { regulated } \\
\text { markets }\end{array}$ \\
\hline 1 & Annual plan & 1939 & None \\
\hline 2 & Ist plan & $1951-56$ & None \\
\hline 3 & $2^{\text {nd }}$ plan & $1956-61$ & None \\
\hline 4 & $3^{\text {rd }}$ plan & $1961-66$ & 1 \\
\hline 5 & $4^{\text {th }}$ plan & $1969-1974$ & None \\
\hline 6 & $5^{\text {th }}$ plan & $1974-79$ & None \\
\hline 7 & Annual plan & $1974-1980$ & None \\
\hline 8 & $6^{\text {th }}$ plan & $1980-1985$ & 3 \\
\hline 9 & $7^{\text {th }}$ plan & $1985-1990$ & 17 \\
\hline 10 & Annual plan & $1991-1992$ & None \\
\hline 11 & $8^{\text {th }}$ plan & $1992-1997$ & None \\
\hline 12 & $9^{\text {th }}$ plan & $1997-2002$ & None \\
\hline 13 & $10^{\text {th }}$ & $2002-2007$ & None \\
\hline 13 & $11^{\text {th }}$ Plan & $2007-2012$ & None \\
\hline Total & \multicolumn{3}{|l}{} \\
\hline
\end{tabular}

Source: Author design, available at Report of Director (Marketing), Deptt. of Agriculture, Govt. of Tripura

In India, the five years plan visualized the importance of regulations of new markets throughout the country. But for Tripura, there is no significant development was made during the first and second five year plan period. The first regulated markets was established at Bishalgarh in 1964 during third five year plan period and after that, whatever development that took place in Tripura in the sphere of marketing was due to the gradual progress made towards the dynamics and governmental efforts. But, the Governmental effort was not sufficient for the development of regulated markets in Tripura.

Present status and requirement of regulated markets in Tripura

In North Eastern region, the regulated markets are found only in Assam, Meghalaya, Arunachal Pradesh, Tripura and Sikkim. The number of regulated markets are high in Assam (226) followed by Arunachal Pradesh (69) and Tripura (21).The other two North Eastern states of Meghalaya (2) and Sikkim (2) have extremely few numbers of regulated markets. The Government of Tripura has enacted the Agricultural Market Produce Act, in the year 1980. The aim of this act is to provide better regulations of buying and selling of agricultural produces and for establishment of regulated markets in the state of Tripura. However, the present status and requirement of regulated markets in Tripura are shown in table-4:

Table-4: Present status and requirement of regulated markets in Tripura.

\begin{tabular}{|c|c|c|c|c|c|}
\hline $\begin{array}{c}\text { Sr } \\
\text { No }\end{array}$ & Region & $\begin{array}{c}\text { Area } \\
\text { (Sq. } \\
\text { Kms.) }\end{array}$ & $\begin{array}{c}\text { Total } \\
\text { regulated } \\
\text { markets }\end{array}$ & $\begin{array}{c}\text { Area } \\
\text { covered } \\
\text { per } \\
\text { market } \\
\text { (Sq. } \\
\text { Kms.) }\end{array}$ & $\begin{array}{c}\text { Requirement } \\
\text { of markets } \\
\text { (Area } \\
\text { required per } \\
\text { market is } \\
78.5 \text { Sq. } \\
\text { Kms.) }\end{array}$ \\
\hline 1 & West & $2,996.82$ & 9 & 332.98 & 38 \\
\hline 2 & South & $2,151.77$ & 6 & 358.62 & 27 \\
\hline 3 & Dhalai & $2,552.47$ & 3 & 850.82 & 32 \\
\hline 4 & North & $2,820.63$ & 3 & 940.21 & 36 \\
\hline Total & Tripura & $10,491.6$ & 21 & 499.6 & 133 \\
\hline
\end{tabular}

Source: Author calculations as per National Commission on Agriculture

In Tripura, the minimum area per regulated market is in West Region, followed by South, Dhalai and North. In Dhalai and North Tripura the area covered per regulated market is extremely high and it is higher than the average area covered per regulated market in Tripura, whereas in South and West Tripura Districts it is below the average area covered per regulated market in Tripura. In this regard, the present number and requirement of regulated markets in Tripura are shown in fig-1. 


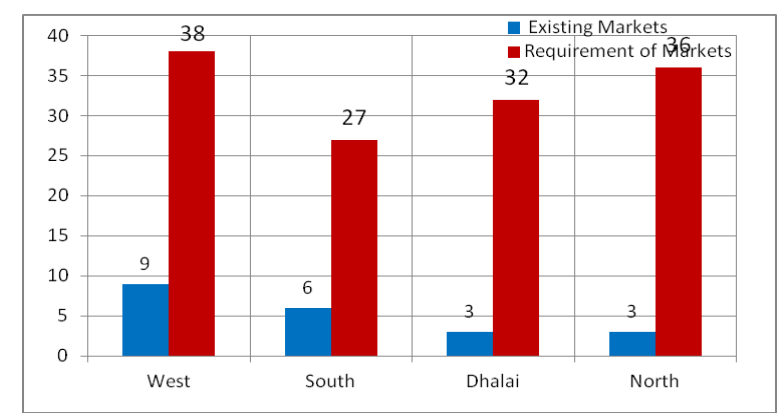

Fig 1: Requirement of regulated Regulated Markets in Tripura

The present number of regulated markets in West, South, the requirement of regulated in those four regions are 38,27 , $32 \& 36$ respectively. Hence, Government needs to take some initiatives for establishment of regulated markets in North Region and Dhalai.

\section{Market practices in regulated markets of Tripura}

The methods of sale in selected regulated markets are almost same. The basic methods followed in selected regulated markets are auctioning method. In very few markets, open agreement method is followed. Forward sale, Jalap sale, Hatta Sale (or sale under cover or secret sale) etc are found ineffective in selected regulated markets of Tripura. The various methods of sales in selected regulated markets are depicted in table-5:

Table-5: Method of sale in selected regulated markets

\begin{tabular}{|l|l|l|l|}
\hline $\begin{array}{c}\text { Sl. } \\
\text { no. }\end{array}$ & $\begin{array}{l}\text { Name of the } \\
\text { market }\end{array}$ & Method of sale & Commodity \\
\hline 1 & Teliamura & Open auction & All commodities \\
\hline 2 & Bishalgarh & Open auction & All commodities \\
\hline 3 & Jampaijalla & Open auction & All commodities \\
\hline 4 & Champaknagar & Open auction & All commodities \\
\hline 5 & Santirbazar & $\begin{array}{l}\text { Open auction \& } \\
\text { Open agreement }\end{array}$ & $\begin{array}{l}\text { All commodities } \\
\text { \& turmeric }\end{array}$ \\
\hline 6 & Nutanbazar & Open auction & All commodities \\
\hline 7 & Chawmanu. & Open auction & All commodities \\
\hline 8 & Panisagar & Open auction & All commodities \\
\hline
\end{tabular}

Source: From Market officials in selected regulated markets. by the market committees and there is no clear specification for selling procedure in regulated markets of Tripura. It is also found that there is no proper method followed for identification of disputes and their settlement. The information relating to markets and produces is known by farmers only by direct interaction or from neighborhoods or from commission agents, or brokers.

\section{Physical performance of regulated markets in Tripura}

With the establishment of regulated market in the state, the Tripura State Agricultural Marketing Board (TSAMB) with financial assistance from the Government of India has created the various infrastructures in the regulated market. A well laid out market yard includes the provision of certain basic amenities and facilities, which are important for the accomplishment of the objectives of the regulated markets. In this connection, various kinds of infrastructure facilities in regulated markets are shown in table-6. Dhalai and North regions are respectively $9,6,3 \& 3$, whereas

No apposite method is found, which is strictly maintained

Table -6: Regulated markets infrastructure facilities

\begin{tabular}{|c|c|c|}
\hline S1. No & $\begin{array}{l}\text { Marketing } \\
\text { infrastructure } \\
\text { facilities }\end{array}$ & $\begin{array}{l}\text { Various kind of infrastructure } \\
\text { facilities }\end{array}$ \\
\hline 1 & $\begin{array}{l}\text { Main Trading } \\
\text { Facilities }\end{array}$ & $\begin{array}{l}\text { a) Common Covered Auction } \\
\text { Halls, b) Common Open } \\
\text { Auction Platforms, c) } \\
\text { Common Drying Yards, d) } \\
\text { Auction Hall \& Godown, e) } \\
\text { Retail shops. }\end{array}$ \\
\hline 2 & $\begin{array}{l}\text { Ancillary Trading } \\
\text { Facilities }\end{array}$ & $\begin{array}{l}\text { a) Storage Godowns, b) Cold } \\
\text { Storage, c) Weighing } \\
\text { Equipment and Facilities ,d) } \\
\text { Processing Units. } \\
\text { e) Grading Equipments, f) } \\
\text { Pledge finance. }\end{array}$ \\
\hline 3 & $\begin{array}{l}\text { Administrative } \\
\text { Facilities }\end{array}$ & $\begin{array}{l}\text { a) Banks, b) Post Office, c) } \\
\text { Police Posts, d) Security } \\
\text { Posts. }\end{array}$ \\
\hline 4 & Farmers Facilities & $\begin{array}{l}\text { a) Farmer's Rest House, b) } \\
\text { Dormitory Accommodation, } \\
\text { c) Agricultural Inputs Shops, } \\
\text { d) Tea Shops. }\end{array}$ \\
\hline 5 & Common Facilities & $\begin{array}{l}\text { a) Bath Rooms, b) Toilets, c) } \\
\text { Urinals, d) } \\
\text { needs/Sundry } \\
\text { Canteen. Shop }\end{array}$ \\
\hline 6 & $\begin{array}{ll}\text { Water } & \text { Supply } \\
\text { Facilities } & \end{array}$ & $\begin{array}{l}\text { a) Open Wells, b) Tube Wells, } \\
\text { c) Municipal Water Supply, d) } \\
\text { Electric Pump Sets, e) } \\
\text { Overhead Tanks, f) Drinking } \\
\text { Water Taps. }\end{array}$ \\
\hline 7 & $\begin{array}{l}\text { Publicity\& } \\
\text { Communicational } \\
\text { Facilities }\end{array}$ & $\begin{array}{l}\text { a) Rate Display Boards, b) } \\
\text { Public Address System, c) } \\
\text { Public Telephone. }\end{array}$ \\
\hline 8 & $\begin{array}{l}\text { Parking and Traffic } \\
\text { Facilities }\end{array}$ & $\begin{array}{l}\text { a) Area for loading and } \\
\text { unloading operations Parking, } \\
\text { b) Internal Road. c) Boundary } \\
\text { Walls, d) Electric Lights, e) } \\
\text { Avenue Shade Trees, f) } \\
\text { Avenue Platforms, g) Sitting } \\
\text { Benches. }\end{array}$ \\
\hline 9 & $\begin{array}{l}\text { Garbage Disposal and } \\
\text { Drainage Facilities }\end{array}$ & $\begin{array}{l}\text { a) Garbage Disposal Systems, } \\
\text { b) Drainage Systems. }\end{array}$ \\
\hline
\end{tabular}

Source: Design by author, available at Chakraborty, K.S (2009), Rural market and marketing in Tripura, pp-53-54.

The several infrastructure facilities are available in all the surveyed areas of regulated markets of Tripura. These are market shed, market stall, market committee office building, electricity facility, facility for weighing, bank, post office, sanitary provision, and transport facility. Market committee offices, light facility are not satisfactory in few markets. Though drinking water facilities are available in surveyed areas, but in few markets, it is not in the centre of the market. It has been found that in all the selected markets grading were taking place only in respect of few commodities and that too to a limited extent. This was partly due to lack of grading equipment and shortage of trained staff to carry out the grading of the produces. However, the various facilities available in surveyed areas have shown table 7 :

Published By: 
Table 7: Various Facilities available in selected regulated

\begin{tabular}{|c|c|c|c|c|c|c|c|c|}
\hline 萢 & 釆 & 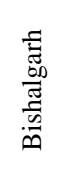 & 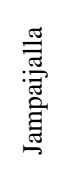 & 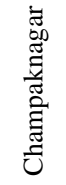 & 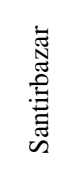 & 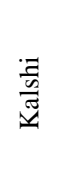 & 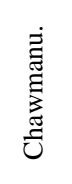 & 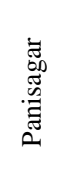 \\
\hline $\begin{array}{l}\text { Market } \\
\text { shed }\end{array}$ & Yes & Yes & Yes & Yes & Yes & Yes & Yes & Yes \\
\hline $\begin{array}{l}\text { Market } \\
\text { Stall }\end{array}$ & Yes & Yes & Yes & Yes & Yes & No & Yes & Yes \\
\hline $\begin{array}{l}\text { Drinking } \\
\text { Water } \\
\text { Facilities } \\
\end{array}$ & Yes & Yes & Yes & Yes & Yes & Yes & Yes & Yes \\
\hline $\begin{array}{l}\text { Market } \\
\text { Committ } \\
\text { ee Office } \\
\text { Building } \\
\end{array}$ & Yes & Yes & Yes & Yes & Yes* & No & Yes & Yes \\
\hline $\begin{array}{l}\text { Electricit } \\
\text { y Facility }\end{array}$ & Yes & Yes & Yes & Yes & Yes & Yes & Yes & Yes \\
\hline $\begin{array}{l}\text { Satisfact } \\
\text { ory Light } \\
\text { facilities }\end{array}$ & Yes & No & No & Yes & Yes & No & No & Yes \\
\hline $\begin{array}{l}\text { Facility } \\
\text { for } \\
\text { weighing }\end{array}$ & Yes & Yes & Yes & Yes & Yes & No & Yes & Yes \\
\hline $\begin{array}{l}\text { Securitie } \\
\mathrm{s} \text { inside } \\
\text { the } \\
\text { market } \\
\text { complex }\end{array}$ & Yes & Yes & $\begin{array}{c}\text { Yes } \\
*\end{array}$ & Yes & Yes & No & Yes & Yes \\
\hline Bank & Yes & Yes & Yes & Yes & Yes & Yes & Yes & Yes \\
\hline $\begin{array}{l}\text { Post } \\
\text { Office }\end{array}$ & Yes & Yes & Yes & Yes & Yes & Yes & Yes & Yes \\
\hline $\begin{array}{l}\text { Sanitary } \\
\text { Provisio } \\
\mathrm{n} \\
\end{array}$ & Yes & Yes & Yes & Yes & Yes & $\begin{array}{c}\text { Yes } \\
*\end{array}$ & Yes & Yes \\
\hline $\begin{array}{l}\text { Transpor } \\
\text { t Facility }\end{array}$ & Yes & Yes & Yes & Yes & Yes & Yes & Yes & Yes \\
\hline
\end{tabular}

Source: Selected eight regulated markets,

From table-7, it is observed that the amenities provided in the Kalshi and Chawmanu market yard are not sufficient. It has found that the important amenities like sanitary arrangements, drinking water, post office, banks, parking space, godowns, water troughts, etc. were not sufficiently found in Champaknagar, Chawmanu, and Kalshi market yard. Canteen, watchman room, cattle shed, etc were found in very few regulated markets. Good street light facilities have been found in Champaknagar and Jampaijalla. On the whole, the Teliamura, and Santirbazar market yards seem to have more amenities than other market yards.

Financial Performance of Regulated markets in Tripura

The progress in respect of regulatory measures and its impact on the market committee was not satisfactory. In 2010-11, the income was more than Rs.3,00,000 in Santirbazar, and Teliamura; Rs. 2,00,000-Rs.3,00,000 in Bishalgarh, and Panisagar; Rs. 1,00,000-Rs.2,00,000 in Jampuijalla and less than 1,00,000 in Chowmanu and Champaknagar. Hence, market committee need to take some initiatives to increase the income in the regulated market of
Chowmanu and Champaknagar. Market committee should make the efficient budget and need to implement it properly for market growth and development of regulated market of Tripura.

Like other markets, more transaction of produces is associated with growth and development of regulated markets. In Tripura, volumes of transactions are different in different regulated markets. The chief sources of arrivals in Tripura through the farmers and middlemen. Arrivals are also brought from the feeder markets. In this context, market arrival in selected regulated markets of Tripura is shown in table-8:

Table 8: Market arrival in selected regulated markets (2008-09)

\begin{tabular}{|c|l|c|}
\hline Sl.No & Name of Market & $\begin{array}{c}\text { Arrival in } \\
\text { 20089(MT) }\end{array}$ \\
\hline 1 & Regulated Market, Panisgar & 1194 \\
\hline 2 & Regulated Market, Chowmanu & 17169 \\
\hline 3 & Regulated Market, Santirbazar & 62264 \\
\hline 4 & Regulated Market, Kalshi & 7287 \\
\hline 5 & Regulated Market, Jampaijalla. & 890 \\
\hline 6 & Regulated Market, Teliamura.. & 90 \\
\hline 7 & $\begin{array}{l}\text { Regulated Market, } \\
\text { Champaknagar }\end{array}$ & 8764 \\
\hline 8 & Regulated Market, Bishalgarh & unknown \\
\hline
\end{tabular}

Source: Report of Director (Marketing), Deptt. of Agriculture, Govt. of Tripura(2009-10)

From table-8, it is found that among the selected regulated markets, the highest arrival is in Santirbazar and followed by Chowmanu and Champaknagar. The minimum arrivals are in the markets of Teliamura. In NIAM (National Institute of Agricultural Marketing Report, 2003), has projected market arrival for different regulated markets of Tripura for the year 2010, 2015, 2020. The market wise projected arrivals in selected regulated markets are shown in table-9:

Table 9: Market -wise projected arrival (2010, 2015 and 2020)

\begin{tabular}{|c|l|r|r|r|}
\hline $\begin{array}{c}\text { Sl. } \\
\text { No } \\
.\end{array}$ & \multicolumn{1}{|c|}{$\begin{array}{c}\text { Name of } \\
\text { Market }\end{array}$} & \multicolumn{1}{c|}{2010} & \multicolumn{1}{c|}{2015} & \multicolumn{1}{c|}{2020} \\
\hline 1. & Panisagar & 1194.74 & 1138.11 & 1481.47 \\
\hline 2. & Chowmanu & 17169.02 & 20536.80 & 23904.58 \\
\hline 3. & Santirbazar & 62264.17 & 82243.65 & 102223.13 \\
\hline 4. & Kalshi & 7287.65 & 9330.37 & 11373.10 \\
\hline 5. & Jampaijalla & 890.97 & 1180.04 & 1469.11 \\
\hline 6. & Teliamura & 90.35 & 106.71 & 123.06 \\
\hline 7. & Champaknagar & 8764.74 & 10764.21 & 12763.68 \\
\hline 8. & Bishalgarh & \multicolumn{3}{|c|}{ unknown } \\
\hline
\end{tabular}

Source: Report of Director (Marketing), Deptt. of Agriculture, Govt. of Tripura(2009-10)

Published By: Blue Eyes Intelligence Engineering \& Sciences Publication 
From table-9, it is found that, for all regulated markets, the projected arrivals will be increased. The projected arrival will be enhanced for five regulated markets namely Panisagar, Chowmanu, Santirbazar, Kalshi, Jampaijalla, \& Champaknagar and reduced for Teliamura. According to this report, the market arrival will become incredibly good for the market Santirbazar. Beside this, NIAM (National Institute of Agricultural Marketing Report, 2003) also estimated the Internal Rate of Return (IRR) for the regulated markets of Tripura. The IRR for the selected regulated markets are placed in table-10:

Table - 10: Internal Rate of Return (IRR) Value (\%) of regulated markets of Tripura

\begin{tabular}{|c|l|l|}
\hline Sl. No & Name of Market & IRR Value $(\%)$ \\
\hline 1 & Panisagar & 14 \\
\hline 2 & Chawmanu & 12 \\
\hline 3 & Santirbazar & 10 \\
\hline 4 & Kalshi & 10 \\
\hline 5 & Bishalgarh & 10 \\
\hline
\end{tabular}

\begin{tabular}{|l|l|l|}
\hline 6 & Jampuijalla & NA \\
\hline 7 & Teliamura & 16 \\
\hline 8 & Champaknagar & 10 \\
\hline
\end{tabular}

Source: NIAM Report 2013

In the selected regulated market, IRR value is higher in the regulated market of Teliamura. In the regulated market of Panisaga \& Chawmanu, the IRR values are 14 \& 12 respectively. For the rest of selected regulated market (Santirbazar, Kalshi, Bishalgarh, Jampaijalla, and Champaknagar) the IRR values are 10 .

\section{Hypothesis testing:}

The required data for hypothesis testing were collected from farmers of eight different selected regulated markets of Tripura. The required data have been presented in table-11

Table-11: Data for Hypothesis testing

\begin{tabular}{|c|c|c|c|c|c|c|c|c|}
\hline \multirow{2}{*}{$\begin{array}{l}\text { Regulated } \\
\text { Markets }\end{array}$} & \multirow[t]{2}{*}{ Region } & \multirow{2}{*}{$\begin{array}{l}\text { Sample } \\
\text { ( farmers) }\end{array}$} & \multicolumn{2}{|c|}{ Price } & \multicolumn{2}{|c|}{ Market intelligence } & \multicolumn{2}{|c|}{ Market practice } \\
\hline & & & affect & $\begin{array}{l}\text { does } \\
\text { not } \\
\text { affect }\end{array}$ & affect & $\begin{array}{l}\text { does not } \\
\text { affect }\end{array}$ & affect & $\begin{array}{ll}\text { does } & \text { not } \\
\text { affect } & \end{array}$ \\
\hline Bishalgarh & South & 15 & 9 & 6 & 8 & 7 & 5 & 10 \\
\hline Champaknagar & & 15 & 8 & 7 & 10 & 5 & 7 & 8 \\
\hline Teliamura, & & 15 & 9 & 6 & 11 & 4 & 8 & 7 \\
\hline Jumpuijala & & 15 & 10 & 5 & 12 & 3 & 11 & 4 \\
\hline Santir Bazar & South & 15 & 10 & 5 & 4 & 11 & 7 & 8 \\
\hline Kalashi. & & 15 & 7 & 8 & 8 & 7 & 5 & 10 \\
\hline Chawmanu. & Dhalai & 15 & 10 & 5 & 9 & 6 & 9 & 6 \\
\hline Panisagar. & North & 15 & 11 & 4 & 9 & 6 & 7 & 8 \\
\hline Total & & 120 & 74 & 46 & 71 & 49 & 59 & 61 \\
\hline
\end{tabular}

Source: Field Survey.

The hypothesis results based on three important factors of regulated markets, which include price, market intelligence and market practice, are as follows(table-12):

Table -12: Hypothesis (Results)

\begin{tabular}{|l|l|c|l|l|}
\hline Sl. No. & Factors & Z-test score & $\begin{array}{l}\mathrm{Z}_{\alpha} \text { at 5\% level of } \\
\text { significance }\end{array}$ & Remarks. \\
\hline 1 & Price & 2.556059 & \multirow{2}{*}{1.64} & Accept $\mathrm{H}_{1}$ \\
\cline { 1 - 2 } 2 & Market intelligence & 2.008332 & & Accept $\mathrm{H}_{1}$ \\
\cline { 1 - 2 } 3 & Market practice & -0.18258 & & Accept $\mathrm{H}_{0}$ \\
\hline
\end{tabular}

Source: Author calculation (from field survey).

Hence, the regulated market system affects the prices of agricultural produces. Beside this, the market intelligence also affects the marketing of agricultural produces. On the other hand, the market practice does not affect by regulated market system of Tripura. 


\section{CONCLUSION}

The Government of Tripura has enacted the Agricultural Market Produce Act in the year 1980. From the study, it is found that there are not significant changes in the regulated market of Tripura. Progress of regulation of markets in the state of Tripura is exceptionally slow. Still, a major part of rural markets are working outside the frame work of regulated market. At the present situation, there is need of more market regulations and proper functioning of regulated markets in this state. It is also suggested that there are urgent requirement of regulated markets in North region and Dhalai region of Tripura

There are improper working and inappropriate practice in the regulated markets of Tripura. Lack of continuity in administration is also a big problem in these regulated markets. Administration is unable to guide and control the markets properly in the state. It is found that management is unable to make proper planning, coordination and implementation of plan. Thus, the regulated markets of Tripura are suffering from lack of facilities, effective management system, market intelligence etc. Market committee need to give focus on those activities. Beside this, the market yards will become competitive in the regulated markets interims of numbers of buyers and sellers, buyers' concentration, freedom of entry exit and mobility.

Scarcity of financial resources is the most important reason mentioned by the committees for not providing all the standard facilities in regulated markets of Tripura. On the other hand, volumes of transactions are also not satisfactory in different regulated markets of Tripura. For this state, out of eight selected markets, special focus should be given for improving the markets arrivals in all selected regulated markets apart from Santirbazar and Chawmanu. However, this is the time for regulated market committee to give emphasis for more arrivals in the regulated markets of Tripura.

The government has taken several steps to streamline the agricultural market system. But, the improper functioning of most of the regulated markets and other handicaps has not changed the conditions noticeably. There need the more construction projects along with regulating measures would go away in improving marketing efficiency. At present situation, Government need to forward to extend the necessary financial help up to a certain level of strengthening each market yard and other market facilities. Beside this, the market committee needs to take initiatives for increasing income for further development of regulated market in Tripura.

\section{REFERENCES}

1. Agarwal, A.K. (1988), Economic Problems and Planning in North East India, Sterling Publishers, New Delhi, pp.3-7.

2. Agarwal, A.N. (2005), Indian Economy-Problems of Development and Planning, Wishwa Prakashan, New Delhi, p.316.

3. Bankar, Basavaraja and Shankaramurthy, H.G.(2000), "Impact of Investment of Performance of Regulated Markets in Karnataka", pp.201-218, edited in Prasad, Jagdish (2000), Encyclopedia of Agricultural Marketing,
Volume 3 -Market Regulation and Development, Mittal Publications, New Delhi.

4. Chakraborty, K.S. and Halder, P. (1995), "Rural Market and Marketing in Tripura with Special Reference to Agricultural Marketing”, Paper Presented in the All India Commerce conference, Rajasthan University, Jaipur.

5. Chakraborty, K.S. (2009), Rural Market and Marketing in Tripura, Mittal Publications, New Delhi, pp.48-52.

6. Datt, Ruddar and Sundharam, K.P.M (2004), Indian Economy, S.Chand \& Company Limited, New Delhi, p.608.

7. Ghosh, M.M (2000), "Growth and Development of Regulated Markets in India" edited in, Prasad, Jagdish (2000), Encyclopedia of Agricultural marketing, Volume 3-Market Regulations and Development, Mittal Publication, New Delhi, P-91.

8. Jairath, M.S. (2000), "Agricultural Marketing Infrastructure in Arid India", Agricultural Situation in India, Vol -1, pp. 127-137.

9. Kerur, N.M. (2010), "Physical and Financial Performance of Selected Regulated Markets in Karnataka”, Karnataka J. Agric. Sci., Vol-23, Issue-2, pp. 379-381.

10. Mallik, Rajib (2012), "Policy Reforms, Performance and Requirements of Regulated Markets in Tripura", Shodh Prerak, A Multidisciplinary Quarterly Refereed Research Journal, Vol- 2, Issue-1, pp.94-99.

11. Mallik, Rajib (2013), "Market Practices in Regulated Markets of Tripura", 15 DAYS, An International Research Referred Journal, Vol-50, pp.27-33.

12. Mallik, Rajib (2013), "Volume of Transactions in Regulated Markets of Tripura", J I GYASA, An Interdisciplinary Refereed Research Journal, Vol.-VI, Issue-1, pp.110-117.

13. Mallik, Rajib (2013), "Market Amenities and Facilities in Regulated Markets of Tripura", ADHIKAR, An International research refereed Journal, Vol-9, Issue-3, pp.28-34.

14. Nicholls, W.H.(1985), "The Place of Agriculture in Economic Development", edited in, Eicher, Carl and Witt, Lawrence (1985), Agriculture in Economic Development, Vora \& Co. Publishers Private limited, Bombay, p-13, also quoted in , Prasad, A. Sivarama (1985), Agricultural Marketing in India, Mittal Publication, New Delhi, P-37.

15. Prasad, A. Sivaram (1985), Agricultural Marketing in India, Mittal Publications, New Delhi, pp.39-41

16. Prasad, Arbind (2000), "Regulated Agricultural Markets in Bihar: Policy and Performance", pp. 65-74, edited in, Prasad, Jagdish (2000), Encyclopedia of Agricultural Marketing, Volume 3-Market Regulation and Development, Mittal Publications, New Delhi.

17. Prasad, Jadish (2000), Encyclopedia of Agricultural Marketing, Volume 1 -Concepts Issues Problems \& Prospects, Mittal Publications, New Delhi, pp.55-58.

18. Prasad, Jagdish (2004), "Agricultural Marketing and Market Development: An Impact Evaluation Study of Regulated Market in Bihar", p.1-64, edited in, Prasad, Jagdish (2000), Encyclopedia of Agricultural Marketing, Volume 3-Market Regulation and Development, Mittal Publications, New Delhi.

19. Prasad, Raj Kumar (2005), "Agricultural Marketing Efficiency -A Study of Impact of Market Regulation in Bihar", Journal of Agricultural Economics, Vol- 43, Issue- 3, pp.55-67.

20. Prasad, Suresh (2000), "Agricultural Regulated Market: A Micro Study”, pp.170-191, edited in, Prasad, Jagdish (2000), Encyclopedia of Agricultural Marketing,

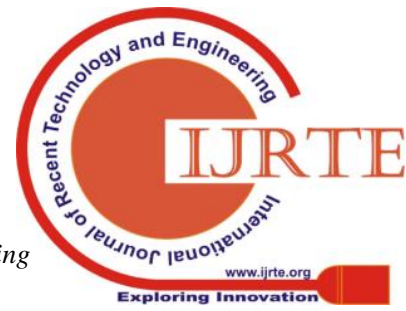


Volume 3 -Market Regulation and Development, Mittal Publications, New Delhi.

21. Raju, V.T. and Rao, D.V.S. (2000), "Role of Regulated Markets in the Marketing of Cultivators", pp.128-134, edited in, Prasad, Jagdish (2000), Encyclopedia of Agricultural Marketing, Volume.3-Market Regulation and Development, Mittal Publications, New Delhi.

22. Report of Director (Marketing) (2007-08), Deptt. of Agriculture, Govt. of Tripura, A Comprehensive Plan for Developments of Markets in Tripura, p.1-7.

23. Sakthivel, G. and Sangeetha, T. (2014), "A Study on Performance of Regulated Agricultural Market in Coimbatore District-Tamilnadu-An Overview", Indian Journal of Applied Research, Vol- 4, Issue-5, pp.95-98.

24. Singh, L.P. (2000), "Regulated Markets in India: Its Shortcoming and Measures", pp.145-160, edited in, Prasad, Jagdish (2000), Encyclopedia of Agricultural Marketing, Volume 4-Marketing Institution, Mittal Publications, New Delhi. 